\title{
The Challenges of Implementing e-Health Technology for Sustainability in Brazil
}

\author{
Jose Rodrigues Filho ${ }^{1}$ \\ ${ }^{1}$ Universidade Federal da Paraíba, Brazil \\ Correspondence: Jose Rodrigues Filho, E-mail: j.r_f@hotmail.com
}

Received: August 24, 2018

Accepted: January 17, 2019 Online Published: March 7, 2019

doi:10.5539/jms.v9n1p55

URL: https://doi.org/10.5539/jms.v9n1p55

\begin{abstract}
In the field of health, the concept of sustainability is not new, but it tends to focus more on environmental health policy. There is an urgent need to assimilate the contribution of social theory into the concept and practice of both sustainability and e-health. The concept of sustainability is very complex, involving environmental, economic and social issues. In addition, in most health sustainability studies, the issue of social sustainability is neglected, despite the fact that social issues are often at the crux of sustainability. E-health is essential for the sustainability of health care, but many e-health projects have failed. Investments in e-health are very high in the whole world, but no explicit research has examined its sustainability. The aim of this paper is to initiate a discussion about sustainability in the implementation and use of e-health in Brazil, with the hope that this will provide a foundation for holistic sustainable e-health systems.
\end{abstract}

Keywords: e-Health, sustainability, ICT, social sustainability, environmental sustainability, economic sustainability, policy

\section{Introduction}

In an age of huge social inequality, economic turbulence and austerity, social unsustainability is very evident, given that four-fifths of the global population is in deficit on all three sustainability fronts. It is widely recognized that there is a need to redress the dysfunctional sustainability deficit, where the crucial task and major challenge is to change social policies, especially in developed countries, that have a long history marked by overconsumption and economic growth.

The concept of sustainability has emerged most strongly in the environmental context, but for completeness it is also important to define it in its economic and social terms (Munasinghe, 1993). Historically, sustainable development was first formulated in relationship solely to environmental concerns. According to the Brundtland Report "Our Common Future" "sustainable development is the development that meets the needs of the present without compromising the ability of future generations to meet their own needs" (WCED, 1987, p. 43).

In the literature of social sciences, issues of sustainability focus on the substantial conflict and the dichotomy that exists on two levels: 1) whether the focus should be on the needs of future or present generations and 2) who is to blame for environmental degradation. This dichotomy between the affluent North and impoverished South has conflicting priorities. While the North (including most proponents of sustainable development) is preoccupied with future generations the South is trying to meet the needs of its current generations (Hatt, Davidson, \& Lock, 2005). In this context, providing for the needs of the present primarily means combating poverty and providing opportunity for a better life for existing populations.

The Brundtland report (WCED, 1987) was in large part dedicated to social issues. However, since then, social issues seem to have been lost behind environmental issues. Sustainability is basically a social problem. It is society and human life that we are trying to sustain. In short, sustainability is a concept that is not bounded by profession or discipline; it is a society-wide problem that requires society-wide participation and cooperation to reach its goals. Due to the complex nature of sustainability, acceptable solutions require intense efforts and cooperation. The work of the physical sciences is the beginning, because they address conditions and changes in the environment in which society exists. On the other hand, social science and other nonphysical disciplines have the capacity to formulate more abstract levels of understanding of the evolution of the institutions and practices of society. 
In this way, the work of various research and academic disciplines serves to improve understanding of the conditions of sustainability, and ideas from social theory have helped provide a new conceptualization of a dynamic sustainability. Consequently, sustainability can be seen as a cross-discipline, cross-society, and a cross-culture concept.

The growing interest in sustainability research is challenging the mainstream scientific methodologies (Jaeger, Bàbara, \& Jaeger, 2011) that "are often poorly equipped to deal with complex sustainability problems" (Popa, Guillermin, \& Dedeurwaerdere, 2015, p. 45). As social, economic and ecological interconnections are becoming more visible, solving sustainability problems involves the "need to move from interdisciplinary approaches to transdisciplinary collaborations, which bring together scientific and extra-scientific expertise" (Popa, Guillermin, \& Dedeurwaerdere, 2015, p. 46), where transdisciplinarity is defined as "a critical and self-reflexive research approach that relates societal with scientific problems" (Jahn, Bergmann, \& Keil, 2012, p.8).

In the field of health, the concept of sustainability is not new, but it tends to focus more on environmental health policy. More recently, the "sustainability paradigm" started to focus many policy spheres, including health care (Cox \& Béland, 2013). By using sustainability narratives in health policy debates in Canada, Bathia \& Orsini (2013) have attempted "to enable greater understanding of sustainability concepts that are particular to the health sector and to shed light on their inherently political - rather than technical - character" p.2. For these researchers, the economic or fiscal sustainability is obvious but is only seen in its narrow sense, in terms of fiscal balance between revenue and expenditures. As key proponents of this definition of sustainability, economic experts from the private sector see healthcare as a marketable commodity that requires "to shift more of it to the private sector" (Bathia \& Orsini, 2013, p.10).

Why is social sustainability neglected in all fields of study, including health and e-health in both developed and developing countries? Social sustainability is not completely clarified to date, but there seems to be a consensus that it is about equality, diversity, democracy and inclusion or interconnectedness. E-health is essential for the sustainability of health care, but many e-health projects in developing countries have failed. In Brazil, the federal government has made certain investments in e-health, but no explicit research has examined its sustainability. The aim of this paper is to initiate a discussion about sustainability in the implementation and use of e-health in Brazil, with the hope that this will provide a foundation for holistic sustainable e-health systems. This will include a review of academic and policy literature about e-health in Brazil in order to expose the different discourses and practices that have taken place on e-health policy and sustainability in this country.

\section{The Triple Bottom-Line Model and the Dilemma of Sustainability}

Although the word sustainability means different things to different people, as used here, it is based on the definition offered in Our Common Futures, the report of the World Commission on Environment and Development (WCED) published in 1987 and often referred to as the Brundtland Report (after the Commission's Chairperson Gro Brundtland). These considerations gave rise to the so-called Triple Bottom Line (TBL) as a concept proposed by sustainability guru John Elkington. He adopted a series of indicators and management and social responsibility tools to account (in a bookkeeping sense) for the costs and benefits of sustainable practice (Elkington 1999). Although the TBL (the three "pillars" of sustainability - environmental, economic, and social) has achieved prominence in many fields, social sustainability has been largely neglected, and under-developed, or over-simplified and under-theorized (Colantonio, 2008). As Melles, de Vere, \& Misic, (2011) stated "even within the business and corporate field there is doubt about the usefulness of 3BL" (p.145).

In the past, various discourses were promoted that branded sustainability as the first wave of 'green' in the 80's and the second wave of 'eco' in the 90's, especially after the Earth Summit in Rio de Janeiro, Brazil in 1992. Following the Brundtland Commission report, attempts were made to adopt the TBL framework, as in the Global Report Initiative (GRI) and several consultancy companies. As a result, the "pressure is now on all organizations (whether private, public or non-governmental) to incorporate a vision for sustainability as part of its core business" (Mitchell, Curtis, \& Davidson (2012, p. 1049)

Despite attracting considerable attention from corporations and academicians globally, there is a more recent literature that critiques the TBL approach (Archel, Fernandez, \& Larrinaga, 2008; Brown, Dillard, \& Marshall, 2006; Milne, Ball, \& Gray, 2005; Norman \& MacDonald, 2004). Critics have argued that reporting at an organizational level makes no sense, as sustainability is a global concept (Mitchell, Curtis, \& Davidson, 2012). In addition, it has been suggested that "the TBL implies that only what can be measured is important" and "encourages environment, economy, and society to be considered as three separate accounts, rather than one" (Milne, 2011, p. 3).

It appears to be almost impossible to reconcile the tension between efforts to enhance sustainability and the need 
to return a profit in the corporate sector. While maintaining business as usual, corporations and the TBL try to deal with a purely market-driven objective rather than social issues. "We too are questioning the effectiveness of engaging organizations in efforts to enhance sustainability, believing that current organizational efforts to monitor and report their sustainability performance is unlikely to result in meaningful change" (Mitchell, Curtis, \& Davidson, 2012).

In short, corporate interpretations of social sustainability have been seen as particularly weak (Dillard, 2009), due to "the lack of a suitable framework to operationalize the concept of social sustainability" (Partridge, 2013, p. 6179). As result of this, since its beginning, "the sustainable development debate was dominated by environmental and economic issues" (Partridge, 2013, p. 6179), and are absent a response to social injustices and the challenges that must be addressed in order to achieve true sustainable development (WCED, 1987).

Due to the priority given to the economic at the expenses of social and environmental issues, the Mickey Mouse model appeared as another version of the TBL. In the Mickey Mouse Model, the larger circle of the economic factor represents Mickey's face, and the smaller circles of the social and environment dimensions represent his ears (Pelletier, Maas, Goralczyk, \& Wolf, 2012). Based on the work of Ross (2013), we try to reformulate the Mickey Mouse model in a way that shows current sustainability debates might more accurately be represented as disproportionate circles in a Venn diagram (i.e., one of Mickey's ears is smaller than the other - Figure 1).

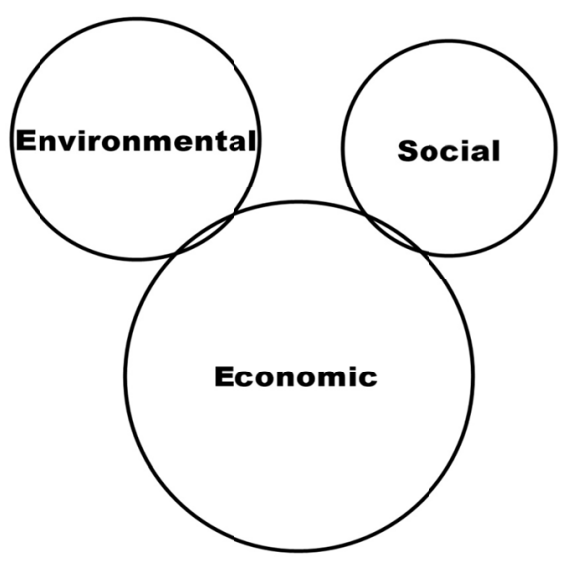

Figure 1. Disproportionate and neglected social sustainability

The definition of sustainability of the World Commission (Brundtland Commission) was formulated in terms of present and future needs. The missing debate over the years since the Brundtland Report is on how to reconcile present and future generational priorities, given the antagonistic character of the dilemma "between protectors (of future generations) and promoters (of risky technologies, of economic development, and of the priorities of present generations)" (Iliescu \& Andrian-Paul, 2015). Consequently, in pursuing sustainability, the so-called "twin horns of the dilemma", population and consumption, must be addressed to challenge the carrying capacity of Spaceship Earth. The existence of the sustainability dilemma requires "social justice to be applied to both present and future generations; it is therefore inherently social” (Hilty \& Ruddy, 2010, p. 11).

The sustainability dilemma in the natural sciences is fundamental and not specific to any particular aspect of sustainable development (SD), recognizing the physical impossibility of extending the present consumption patterns of the industrialized countries to all parts of the world. For some authors in the natural sciences, "there is no meaningful way of assigning the sustainability dilemma to one or more aspects or 'dimensions' of SD". As a consequence, "there is no meaningful interpretation of terms such as 'ecological sustainability', 'environmental sustainability', 'economic sustainability', 'social sustainability' or 'cultural sustainability' as long as 'sustainability' refers to SD” (Hilty \& Ruddy, 2010). The sustainability dilemma must be solved in any case, irrespective of the specific focus of a given discourse (Hilty \& Ruddy, 2010). In short, for the natural sciences none of these dimensions or goals can be achieved without preserving "the life-sustaining services of nature", which are not replaced by technical means (WRF, 2008).

The "three-pillar model" or the TBL model is common in the political discourse, but a critical reflection on it is often lacking. The field of Computational Sustainability (CompSust) connected with the Institute for 
Computational Sustainability (ICS) has attempted "to apply techniques of computer science, information science, operations research, applied mathematics, and statistics for balancing environmental, economic, and societal needs for sustainable development" (Hilty \& Aebischer, 2015, p. 13). At the same time it is recognized that "environmental, economic and societal issues are not usually studied in those disciplines" (Hilty \& Aebischer, 2015, p. 13). For these authors, a balance can only exist between entities that are in principle independent but connected. "By definition, the economic system forms part of society" (Hilty \& Aebischer, 2015, p. 8).

Finally, the "social and natural science disciplines now beginning to recognize the importance of the other", and the suggestions are that "a more cross-disciplinary approach is now developing" (Dillard, Dujon, \& King, 2009, p. 1). Fortunately, now there are a range of models for conceptualizing the relationship between the different dimensions of sustainability, in an attempt to integrate the social dimension and its interrelatedness with the environmental dimension (Cuthill, 2010).

\section{ICT Support for Sustainability}

In studying the relationship of Information and Communication Technologies (ICTs) and sustainable development, the role and transformational power of ICT has been explored, including both its positive and negative impacts. Many have pointed out the crucial role that ICT could play in sustainable development, but "there is not much political attention being paid to the 'ICT for sustainability' issue yet" (Hilty, Lohmann \& Huang, 2011, p.16).

The normative implications of the Brundtland definition have been underestimated in the discussion of sustainable development during the last two decades, leading to misconceptions distorting the role of information and communication technologies (ICTs) in sustainable development. It is argued that ICTs can only support sustainable development if they are applied as enablers of dematerialized (less material-intensive) types of consumption (Hilty \& Ruddy, 2010). So, instead of ICT in SD, a differentiated concept (ICT for SD) was endorsed in the First Conference of ICT for Sustainability (ICT4S) held in Zurich in 2013, referring to "sustainable development in the same sense used by the Brundtland Report" (Hilty \& Aebischer, 2015, p.18).

The approaches to using ICT in the service of sustainability that have emerged during the last two decades have been classified as: Environmental informatics (E-Environment), Green information technology or Green IT/ICT and Sustainable Human-Computer Interaction - HCI (Hilty, Lohmann \& Huang, 2011). These approaches focus on environmental and economic sustainability. Based on an economic and historical perspective, Hilty, Lohmann \& Huang, (2011) "have argued that to the degree that these approaches depend on efficiency strategies, they will remain unsuccessful", p.24.

ICT for sustainability (ICT4S) is seen as a growing research area exploring how information technologies are used with a sustainability purpose ((Hilty, Lohmann \& Huang, 2011). Most ICT4S research has focused on both the positive and negative impacts of hardware such as use of the internet (Arushanyan, Ekener-Petersen, \& Finnveden, 2014; Malmodin, Moberg, Lundén, Finnveden, \& Lövehagen, 2010; Weber, 2010) and the generation of e-waste (Shakila, Björklund, Ekener-Petersen, 2013) or on increasing efficiency in the use of technologies and increasing dematerialization (Climate Group, 2008). There is no doubt that the production and use of ICTs contribute to the environmental crisis, considering that the consumption of ICTs is on the rise. So, ICT has become a major contributor to environmental contamination "at all stages in its lifecycle: in its production, its use and in its disposal" (Elliot, 2007, p.100).

It is estimated that the "ICT sector's contribution to global CO2 emissions - currently $2-3 \%$ - is projected to double by 2020 under business-as-usual scenarios" (Maclean, Akon, \& Egede-Nissen, 2011, p. 17). On the other hand, E-waste, or electronic waste, comprises discarded electronic appliances such as laptop and desktop computers, mobile phones, liquid crystal display (LCD) monitors, television and computers monitors, cathode ray tube (CRT), keyboards, computers mice and printers that are always disposed in landfills, causing high risks of contamination, and damaging human health Therefore, E-waste and its potential environmental contaminants is a growing problem, especially in developing countries. Although illegal under the Basel Convention, "rich countries export an unknown quantity of E-waste to poor countries" (Robinson, 2009, p. 183).

It is recognized that E-waste is more hazardous than other wastes, but little research has been conducted in this area to date (Kumar \& Kumar, 2014). The narrow focus of ICT for sustainability and its low impact is recognized; in particular it does not take into account the social aspects of sustainability, which have been neglected so far (Johann \& Maalej, 2013).

The more recent approach to sustainability and ICT is the emergence of Sustainable Human-Computer Interaction ( $\mathrm{HCI})$, that tends to focus on engineering and on environmental aspects of sustainability, "leaving out 
two of the three equally important pillars of sustainable developments" (Hauser, Desjardins, \& Wakkary, 2013, p. 2). However, some researchers have advocated "the continuing promotion of HCI work within both social and economic sustainability" (Dillahunt, 2013, p. 2), now that a small but growing body of HCI research addresses issues of social sustainability explicitly in topics of social justice, politics, citizen engagement and equity in health services (Beenish, Connelly, Siek, \& Welch, 2011; Erete, 2013).

With regard to the Information Systems (IS) domain it is argued that sustainability appears to be marginal in comparison to other disciplines, and the main focus of IS research on sustainability over the last few years was on providing some initial solutions to environmental problems (Chasin, 2014; Melville, 2010; Watson, Boudreau, \& Chen, 2010). As the body of research on sustainability in Information Systems grows, the exact meaning of sustainability is increasingly becoming opaque and a source of uncertainty, due to the lack of "an integrative definition of the sustainability concept" (Chasin, 2014, p. 342). For Chasin (2014), who has reviewed articles on sustainability in the domain of Information Systems, the majority of them "fail to provide explicit definitions of sustainability and focus on ecological challenges, therefore neglecting the social and economic dimensions of sustainability" p.358).

The global challenge to ensure sustainability in e-health systems implementation in both developed and developing countries is recognized, taking into account that only a few E-Health projects have managed to sustain themselves (WHO, 2010). Due to large differences in systems environments, it is clear that developing countries exhibited many more failures in E-Health implementations than have developed countries. In short, despite the efforts to deliver effective and sustainable e-health projects, in a resource-constrained setting e-health projects are rarely sustainable, due to inadequate ICT infrastructure, and a shortage of ICT skills, financial resources and evaluation.

\section{E-Health in Brazil}

E-health is not new in Brazil. Since the 1970s e-health systems have appeared in the country, but in a very fragmented way. Due to the fragmentation of these systems, it is argued that they have not improved patient care and management decisions (Moraes, 1994). Despite high investments in e-health over the last two decades, Brazil has trailed some African countries in terms of health information and data recording, according to international reports of country health care indicators. Even some bad indicators have not been published by the government over the years (e.g. caesarean section rates that have been registered as the highest in the world) (Rodrigues, 1987).

Many e-government initiatives, including e-health applications, are based on a traditional top-down model or market and specialist-driven approach to information technology, which benefit corporate interests and health care administration, but disregard patient health care needs (Rodrigues Filho, 2010). As in many other developing countries, "the potential benefits and ultimate goal to achieve quality of care improvements through IT are not met (Luna, Almerares, \& Mayan, 2014), making sustainability visible in e-health technology, especially in terms of its design, development, stakeholders participation, and implementation (Gordon, 2007; Luna, Almerares, \& Mayan, 2014; Fanta, Pretorious, \& Eramus, 2015).

During the last decade more than 700 e-health applications have been registered in operation at municipal, state and federal government levels. Eleven of them have been mandated by the Ministry of Health for use at all levels of government, due to their importance to the National Health Systems. These systems are known as health information systems of the national base, such as the Mortality Information System, Information Systems for Breast Cancer, Ambulatory Care Information System, Primary Health Care Information Systems, and so on (Brasil, 2011). Despite many e-health applications in Brazil, we focus on the National Health Card, one of the most well-known e-health systems in the country. The National Health Card, known as the SUS Card, is a magnetic card used primarily to prove identity in the National Health System (Sistema Único de Saúde - SUS). The Ministry of Health is a federal government sector that has been responsible for the highest information technology investments in the country over the years.

For some considerable time, the federal government has tried to reduce the fragmentation of e-health applications in Brazil, and the National Health Card (SUS Card) was introduced for the purpose of improving the interoperability of these fragmented information systems (Brasil, 2011). Since its introduction in 1999 as a pilot project, more than 13 million patients in 44 Brazilian municipalities, were registered as SUS Card users. After many complaints, the pilot project was interrupted in 2003, and other technological initiatives linked to the SUS Card were implemented to register individual patients of the National Health System. The National Patient Registration now covers the whole country with more than 140 million patients. This National Patient Registration initiative is the first step to implementing the SUS Card, seen as a tool to improve efficiency and 
patient care (Brasil, 2011).

\section{Method}

In this paper, an exploratory research method is used, mostly based on reviewing academic literature and Brazilian government reports on e-health systems, as well as international literature on e-health and sustainability. This is an attempt to examine the importance of sustainability in information technology in general and health information technology, in particular. Literature on e-health in Brazil, especially on the national health card, was examined from major Brazilian health academic journals such as Cadernos de Saúde Pública, Ciência e Saúde Coletiva, Saúde e Sociedade, and Saúde em Debate, apart from several government reports, and conference papers.

\section{Results}

Despite quite high investments in the National Health Card in Brazil, not much appears to have been gained during the SUS card's implementation, and ultimate interruption (Brasil, 2011; Moraes \& Vasconcelos, 2005). With the promise of digital integration and interoperability, the claims are that more than 200 million US dollars were spent on this project without implementing any social controls (Silva \& Moraes, 2012). In its second master plan for the development of information and information technology in health in Brazil, the Brazilian Association of Graduates in Collective Health (ABRASCO) stated that both the SUS Card project and other different initiatives in the health sector brought few benefits to the population and to the management of the National Health System (ABRASCO, 2013). ABRASCO has been very active in the debate on Brazilian health reform and national health information and health information technology policy, recognizing the loss of public resources and the negligible results of e-health technology such as the SUS Card (ABRASCO, 2013).

Although there has been a lack of transparency in e-health investments by Brazil's Federal government, it is recognized that they have increased significantly since the introduction of the SUS Card. While expenditures in the SUS Card increased during the last decade, expenditures in other basic social programs decreased. It appears, for example, that the Ministry of Health's increased expenditures on the SUS card resulted in decreases in basic social programs such as vaccination, oncological cancer prevention/treatment, and adolescent social re-insertion, that could have been of benefit to the country's poor population (Rodrigues Filho, 2010).

The fragmentation of information in Brazil is the result of the fragmentation of the Brazilian State (Moraes \& Gomez, 2007). This situation affects power relations among Federal, State, and Municipal governments, as well as the private sector, which wants to maintain the status quo of information practices in health. For the private sector, fragmentation ensures that the e-health market, in which the same application can be sold to different institutions in the health sector, allows different technical government agencies to maintain their power positions (Moraes \& Gomez, 2007; Fornazin \& Joia, 2015). In this case, a citizen or patient, who should have full rights to personal health information, becomes merely a source of information for the government. This has emphasized a technical worldview in which information is discussed only by experts in the ICT domain, excluding the population from this process. According to Moraes \& Gomez (2007) there is an urgent need to ensure the democratic dissemination of health information to its rightful owners, as a fundamental human right.

During the last few years there has been an intense debate on the construction of a national information and health informatics policy in Brazil that would be oriented towards reinforcing the right to universal health, the democratization of access to health information, and the quality of health information. This would encompass the digital inclusion of different segments of Brazilian society (ABRASCO, 2013). How should this information and health informatics policy be constructed while political, social and economic forces are under constant tension? These challenges are recognized, especially because their resolution requires the full participation of society (Branco, 2006; Moraes \& Gomez, 2007). However, despite this debate on a national information and health informatics policy, as yet there is no effective legitimation of this policy. A technological imperative is definitely evident in the present context of the construction of a Brazilian national information and health informatics policy, named PNIIS - Política Nacional de Informação e Informática em Saúde (Cavalcante \& Kerr Pinheiro, 2013).

The use of the traditional top-down model or the 'tool-approach' to information technology seems to prevail in the Brazilian health sector. This makes it clear that e-health, as with many other information technology initiatives, has a politics that is never neutral. This approach results in public services becoming less accountable, encouraging bureaucrats to waste resources, tolerate inefficiency, mistakes and corruption.

There is a need to implement information and health informatics public policy in Brazil in order to avoid a lock-in effect due to inadequate information technology structures. These developments are influenced by 
politicians, bureaucrats and consultants who continually circulate between government agencies and the market, in particular when political campaigns are supported by information technology corporations. In other words, it is necessary to avoid the subordination of public policies to the interests of private corporations, which can result in poor outcomes in the health sector.

For some authors (Walsham \& Sahay, 2006) theories of sociology and political science can contribute to improving the understanding of information technology in developing countries. The literature reviewed in this work seemed to lean in the direction of supporting the integration of theoretical alternatives, leading to a better understanding of e-health implementations in Brazil. In addition, no work was found that addressed explicitly the relationships between sustainability and e-health. However, contrary to the official discourse, most of the academic publications on e-health in Brazil seem to be very rich in their support of social sustainability, even implicitly. This was found to be especially the case when reviewing topics related to information and health informatics democratization, civic engagement, social justice, politics, digital inclusion, and health for all. E-health implementation has never been studied under the social sustainability approach of sustainable development, explicitly. But in this work an attempt has been made to emphasize its use in both developed and developing countries. In Table 1, a social sustainability framework is proposed for the study of e-health implementation in Brazil. The Brazilian literature has emphasized the engaged governance or e-health democratization in this framework, as well as social infrastructure, as important factors in e-health implementation in Brazil.

Table 1. Social sustainability and sustainability factors

\begin{tabular}{ll}
\hline Social Equity \& Justice & $\begin{array}{l}\text { Peace, human rights, citizenship, equitable access to essential services (health, education, housing, basic } \\
\text { needs, quality of life, safety and security, job opportunities, etc) }\end{array}$ \\
\hline Engaged Governance & Participatory democracy: politics, policies, decision making, bottom up empowerment \\
\hline Socio-Cultural Respect & Understanding and respect for local traditions and values \\
\hline $\begin{array}{l}\text { Social Infrastructure (E-Health } \\
\text { Implementation) }\end{array}$ & $\begin{array}{l}\text { Physical infrastructure which addresses capacity for participation, locally based services, opportunities } \\
\text { for social interaction, information needs, technology and e-health implementation }\end{array}$ \\
\hline
\end{tabular}

The international literature is full of examples of factors which restrain or promote e-health implementation. In this work, e-health implementation factors are mentioned as an expansion of the social sustainability framework (Table 2). In the Brazilian literature, context, conflict among stakeholders, project design (costs and conditions for success), e-health design, and resource capability were responsible for the failure and unsustainability of the Brazilian e-health card. Finally, some Brazilian authors have explicitly expressed the need to implement sustainable e-health technologies in the country, considering that the implementation of the National Health Card - the SUS Card - turned out to be unsustainable.

The use of the traditional top-down model or "tool-approach" to information technology seems to work in the Brazilian context in favor of the interests of corporate actors and health care administration rather than basic health care needs. There is no sign that the SUS card has opened a space for public deliberation, contributing to improve transparency, accountability, and sustainability in the provision of health care. This type of failure is a phenomenon which is well-known globally (deLeon \& deLeon 2002). Top-down policies and implementations, whether they relate to information technology or any other operational systems, are prone to hierarchical decisions and unduly optimistic expectations that are unlikely to be met. Bottom-up or grass roots implementations tend to be more reflective of community interests and are more likely to be democratic, realistic and practical, and encourage participation and meet the needs of those they affect the most. These approaches are therefore more likely to be successful.

Table 2. E-health implementation factors

\begin{tabular}{ll}
\hline Context & Socioeconomic factors, resources and capabilities (lack of e-health skills) \\
\hline Outcomes & $\begin{array}{l}\text { Project design (funding and costs), e-health design (local context, user friendship, patient and medical professionals } \\
\text { participation, interoperability standards), improved health care management, decision support, and quality of care }\end{array}$ \\
\hline Stakeholders & Conflict, lack of consensus, decision power, commitment among key stakeholders \\
\hline Ethical & Privacy and confidentiality in sharing patient data base at local, regional and national levels \\
\hline
\end{tabular}


Finally, the discussion about the relationship between e-health and sustainability is almost non-existent in the literature. Although the attempt made here is quite rare, it is recognized that any e-health project to be sustainable needs to consider other dimensions of sustainability, such as environmental and economic. It is proposed that further research take into account the need for sustainable e-health implementation. This comes at a time when e-health potential in the health sector could be used to attend the worldwide increasing threat and awareness of the societal consequences of an aging population and the resulting increased need for suitable healthcare resources.

\section{Conclusion}

Sustainability is not new in the field of health, especially in the field of environmental health, but little research has been conducted in the field of sustainability and e-health. In the Portuguese language no work was found covering this topic explicitly. The concept of sustainability is very complex, involving environmental, economic and social issues. In addition, in most health sustainability studies, the issue of social sustainability is neglected, despite the fact that social issues are often at the crux of sustainability.

In this study it was recognized that the field of sustainability is very important in the study of e-health systems, especially in topics related to development, implementation and use, in addition to e-health policy. Recently, the European Union recognized sustainability as one of its overarching goals, pointing out that it "offers plenty of opportunities for research in areas like health, energy, climate change, and food, and it encourages sustainability oriented research in fields as diverse as new production technologies and the humanities" (Jaeger, Tàbara, Jaeger, 2011). In addition, it is mentioned that "Sustainability is a word full of promises, evoking peace, welfare, and harmony with nature. No wonder Europe has a strong wish for sustainability. Does it also have the will?" (Jaeger, Tàbara, Jaeger, 2011). In addition, The European Commission states that e-health will play a key role in structural reforms that are needed to ensure the sustainability of health systems while securing access to services for all citizens (European Commission, 2012).

Borgonovi \& Compagni (2013) have stated that health care policy should not focus on finance and money, but rather on its social aspects by involving patients in planning, and building political consensus setting aside finance as a factor. For them, the new conceptualization of sustainability has to be reframed and expanded "to include its additional facets, particularly its social and political dimensions" (p. s34).

The aims of ICT for Sustainability, or ICT4S for short, are to make ICT goods and services more sustainable, creating, enabling and encouraging sustainable patterns of production and consumption by means of ICT. The use of empirical methods from the social sciences can encourage a more critical perspective of the interactions between ICT design and human behavior in order to harness ICT for sustainable development. The worldwide missing debate on ICT for Sustainability (ICT4S), according to the original definition of the Brundtland Commission, requires new research methods, especially in the area of transdisciplinary research.

There is an urgent need to assimilate the contribution of social theory into the concept and practice of both sustainability and e-health. While the official discourse in Brazil tends to treat e-health as a "tool-approach", most academicians tend to treat the topic using alternative theoretical approaches from the social science, especially from sociology and political sciences. The implementation of the National Health Card (SUS Card) in Brazil is a clear example of e-health unsustainability. Many factors have contributed to this failure, and it is mentioned in the literature on e-health implementation in developing countries. The lack of democratic participation and the uneven power relations, with dominant actions of the private sector in the decision making process, were emphasized in the Brazilian literature that was reviewed on this topic.

\section{Acknowledgement}

This research was supported by the Universidade Federal da Paraíba, Brazil, and McMaster University, Canada. I would also like to show my gratitude to Professor Norm Archer at McMaster University, who advise me as a visiting scholar, and for his comments that greatly improved the manuscript.

\section{References}

ABRASCO (Associação Brasileira de Pós-Graduação em Saúde Coletiva). (2013). $2^{\circ}$ Plano Diretor para o desenvolvimento da informação e tecnologia de informação em saúde (2 $2^{\circ}$ PlaDITIS 2013-2017) $2^{\mathrm{a}}$ versão, junho/2013.

Archel, P., Fernandez, M., \& Larrinaga, C. (2008). The organizational and operational boundaries of triple bottom line reporting: A survey. Environmental Management, 4l(1), 106-117. https://doi.org/10.1007/s00267-007-9029-7 
Arushanyan, Y., Ekener-Petersen, E., \& Finnveden, G. (2014). Review: Lessons learned-Review of LCAs for ICT products and services. Comput. Ind., 65(2), 211-234. https://doi.org/10.1016/j.compind.2013.10.003

Beenish, C., Connelly, K., Siek, K. A., \& Welch, J. L. (2011). The Design of a Mobile Portion Size Estimation Interface for a Low Literacy Population. In 5th International Conference on Pervasive Computing Technologies for Healthcare, p. 10.

Bhatia, V., \& Orsini, M. (2013). "Sustainability" Narratives in Canadian Health Policy Debates. International Conference on Public Policy (ICPP), Grenoble, June 26-28, 2013.

Borgonovi, E., \& Campagni, A. (2013). Sustaining Universal Health Coverage: The Interaction of Social, Political and Economic Sustainability. Value in Health, (16), S34-S38. https://doi.org/10.1016/j.jval.2012.10.006

Branco, M. A. F. (2006). Informação em saúde: uma ciência e suas políticas em uma nova era. Rio de Janeiro: Editora Fiocruz.

BRASIL. CONSELHO NACIONAL DE SECRETÁRIOS DE SAÚDE. Ciência e Tecnologia em Saúde. Brasília: CONASS (2011). (Coleção Para Entender a Gestão do SUS 2011).

Brown, D., Dillard, J., \& Marshall, R. S. (2006). Triple Bottom Line: a business metaphor for a social construct. Department d'Economia de l'Empresa. Universitat Autonoma de Barcelona. Barcelona, Spain. Retrieved from http://www.recercat.cat/bitstream/handle/2072/2223/UABDT06-2.pdf? sequence=1

Cavalcante, R. B., \& Kerr Pinheiro, M. C. (2013). Contexto atual da construção da política nacional de informação e informática em saúde (PNIIS). XIV Encontro Nacional de Pesquisa em Ciência da Informação (ENANCIB).

Chasin, F. (2014). Sustainability: Are we all talking about the same thing? State-of-the-art and proposals for an integrative definition of sustainability for information systems. $2^{\text {nd }}$ International Conference on ICT for Sustainability (ICT4S, 2014). https://doi.org/10.2991/ict4s-14.2014.42

Climate Group, The. (2008). Smart2020: Enabling the low carbon economy in the information age. GeSI (Global sustainability initiative). Retrieved from http://www.theclimategroup.org/assets/resources/publications/Smart2020Report.pdf

Colantonio, A. (2008). Traditional and emerging prospects in social sustainability. Measuring social sustainability: Best practices from urban renewal in the EU, 2008/02. EIBURS Working Papers Series, November 2008, Oxford, UK. Oxford Institute for Sustainable Development (OISD).

Cox, R. H., \& Béland, D. (2013), Valence, policy ideas, and the rise of sustainability. Governance, 26(2), 1-22. https://doi.org/10.1111/gove.12003

Cuthill, M. (2010). Strenthing the 'social' in sustainable development: Developing a conceptual framework for social sustainability in a rapid urban growth region in Australia. Sustainable Development, 18, 362-373. https://doi.org/10.1002/sd.397

deLeon, P., \& deLeon, L. (2002). What ever happened to policy implementation? An alternative approach. Journal of Public Administration Research and Theory, 12(4), 467-492. https://doi.org/10.1093/oxfordjournals.jpart.a003544

Dillahunt, T. (2014). Toward a deeper understanding of sustainability within HCI. CHI 2014 (Association for Computing Machinery Conference on Human Factors in Computing Systems), Toronto, Canada, 26 Apr-1 May.

Dillard, J. F., Dujon, V., \& King, M. C. (Eds). (2009). Understanding the social dimension of sustainability. New York: Routledge.

Elkington, J. (1999). Triple bottom line revolution: reporting for the third millennium. Australian CPA. 69:75.

Elliot, S. (2007). Environmentally Sustainable ICT: A critical topic for IS Research. Pacific Asia Conference on Information Systems - PACIS $2007 \quad$ Proceedings. Retrieved from $\mathrm{http}: / /$ aisel.aisnet.org/cgi/viewcontent.cgi?article $=1115 \&$ context=pacis 2007

Erete, S. (2013). Empowerment through community crime prevention technologies. ACM Interactions. https://doi.org/10.1145/2517444

European Commission. (2012). eHealth Action Plan 2012-2020. Retrieved from http://ec.europa.eu/health/ehealth/key_documents/index_en.htm 
Fanta, G. B., Pretorious, L., \& Eramus, L. (2015). An evaluation of ehealth systems implementation framework for sustainability in resource constrained environments: A literature review. International Association of Management for Technology (IAMOT), Conference Proceedings.

Fornazin, M., \& Jóia, L. A. (2015). Articulando perspectivas teóricas para analisar a informática em saúde no Brasil. Saúde e Sociedade, 24(1), 46-60. https://doi.org/10.1590/S0104-12902015000100004

Gordon, A. N. (2007). Towards a sustainable framework for computer based health information systems (CHIS) for least developed countries (LDCs). Int $J$ Health Care Quality Assurance, 20(6), 532-544. https://doi.org/10.1108/09526860710819468

Hatt, K. C., Davidson, D. J., \& Lock, I. (2005). Power and Sustainability. In D. J. Davidson \& K. C. Hatt (Eds.), Consuming Sustainability: Critical Social Analyses of Ecological Change. Halifax, NS: Fernwood Publishing Company Ltd.

Hauser, S., Desjardins, A., \& Wakkary, R. (2013). Rethinking and Envisioning Sustainable HCI and the Role of Interaction Design. CHI'13, April 27 - May 2, 2013, Paris, France.

Hilty, L. M., \& Aebischer, B. (2015). ICT for sustainability: an emerging research field. In L. M. Hilty \& B. Asbischer (Eds.), ICT Innovations for Sustainability. Advances in Intelligent Systems and Computing 310. Springer International Publishing. https://doi.org/10.1007/978-3-319-09228-7_1

Hilty, L. M., \& Ruddy, T. F. (2010). Sustainable Development and ICT interpreted in a natural science context. The resulting research question for the social sciences. Information, Communication \& Society, 13(1), 1-22. https://doi.org/10.1080/13691180903322805

Hilty, L. M., Lohmann, W., \& Huang, E. M. (2011). Sustainability and ICT - An overview of the field. Notizie di POLITEIA, XXVII(104), 1328.

Iliescu, A.-P. (2015). The "missing link" polarization and the need for "trial by jury" procedures. In D. Birnbacher \& M. Thorseth (Eds.), The Politics of Sustainability: Philosophical perspective. Routledge, Abingdon.

Jaeger, C. C., Bàbara, J. D., \& Jaeger, J. (2011). European Research on Sustainable Development Volume 1: Transformative Science Approaches for Sustainability. https://doi.org/10.1007/978-3-642-19202-9

Jahn, T., Bergmann, M., \& Keil, F. (2012). Transdisciplinarity: between mainstreaming and marginalization. Ecological Economics, (79), 1-10. https://doi.org/10.1016/j.ecolecon.2012.04.017

Johann, T., \& Maalej, W. (2013). Position Paper: The social dimension of sustainability in requirements engineering. RE4Susy - Requirements Engineering for Sustainable Systems. Proceedings of the $2^{\text {nd }}$ International Workshop on Requirements Engineering for Sustainable Systems, Rio, Brazil, Jul7 15. Retrieved from http://ceur-ws.org/Vol-995/paper4.pdf

Kumar, S. N., \& Kumar, J. (2014). E-Waste: Health impacts in developing countries. EHS Journal.

Luna, D., Almerares, A., \& Mayan, J. C. (2014). Health informatics in developing countries: Going beyond pilot practices to sustainable implementation: A review of the Current Challenges. Health Informatics Research, 20(2), 3-10. https://doi.org/10.4258/hir.2014.20.1.3

Maclean, D., Akon, B., \& Egede-Nissen, B. (2011). ICTs, sustainability and the green economy. IISD (International Institute for Sustainable Development). Retrieved from https://www.iisd.org/sites/default/files/pdf/2011/icts_sustainability_green_eco.pdf

Malmodin, J., Moberg, Å., Lundén, D., Finnveden, G., \& Lövehagen, N. (2010). Greenhouse gas emissions and operational electricity use in the ICT and entertainment \& media sectors. Journal of Industrial Ecology, 14(5), 770-790. https://doi.org/10.1111/j.1530-9290.2010.00278.x

Melles, G., de Vere, I., \& Misic, V. (2011). Socially responsible design: thinking beyond the triple bottom line to socially responsive and sustainable product design. CoDesign, 7(3-4), 143-154. https://doi.org/10.1080/15710882.2011.630473

Melville, N. (2010). Information systems innovation for environmental sustainability. MIS Q., 34(1), 1-21. https://doi.org/10.2307/20721412

Milne, M. J. (2011). Sustainability, Environmental Pragmatism and the Triple Bottom Line: Good Question, Wrong Answer? Launceston, Australia: The 10th Australasian Conference on Social and Environmental Accounting Research, 5-7 Dec 2011. 
Milne, M. J., Ball, A., \& Gray, R. (2005). From soothing palliatives and towards ecological literacy: A critique of the Triple Bottom Line. Paper presented at the International Sustainability Conference, 13-14 October, University of Basel, Switzerland.

Mitchell, M., Curtis, A., \& Davidson, P. (2012). Can triple bottom line reporting become a cycle for "double loop" learning and radical change? Accounting, Auditing \& Accountability Journal, 2(6), 1048-1068. https://doi.org/10.1108/09513571211250242

Moraes, de I. H. S., \& Vasconcelos, M. M. (2005). Politica nacional de informação e comunicação em saúde: um pacto a ser construído. Saúde em Debate, 29(69), 86-98.

Moraes, I. (1994). Informações em Saúde: da Prática Fragmentada ao Exercício da Cidadania. São Paulo e Rio de Janeiro: ABRASCO.

Moraes, I. H. S., \& Gomez, M. M. G. de. (2007). Informação e informática em saúde: caleidoscópio contemporâneo da saúde. Ciência \& Saúde Coletiva, Rio de Janeiro, 12(3), 553-565. https://doi.org/10.1590/S1413-81232007000300002

Munasinghe, M. (1993). Environmental Economics and Sustainable Development. World Bank, Washington DC, USA. https://doi.org/10.1596/0-8213-2352-0

Norman, W., \& MacDonald, C. (2004). Getting to the bottom of the "Triple Bottom Line"? Business Ethics Quarterly, 14(2), 243-262. https://doi.org/10.5840/beq200414211

Partridge, E. (2013). Social Sustainability, Encyclopedia of Quality of Life Research, Springer Reference.

Pelletier, N., Maas, R., Goralczyk, M., \& Wolf, M.-A. (2012). Towards a life cycle based European Sustainability footprint framework - Theory, concepts, applications. JRC Scientific and Policy. European Union. Institute for Environment and Sustainability. Retrieved from http://publications.jrc.ec.europa.eu/repository/bitstream/JRC74553/lbna25501enn.pdf

Popa, F., Guillermin, M., Dedeurwaerdere, T. (2015). A Pragmatist approach to transdisciplinarity in sustainability research: From complex systems theory to reflexive science. Futures, (65), 45-56. https://doi.org/10.1016/j.futures.2014.02.002

Robinson, B. H. (2009). E-waste: An assessment of Global Production and Environmental Impacts. Science of the Total Environment, 408(2), 183-191. https://doi.org/10.1016/j.scitotenv.2009.09.044

Rodrigues Filho, J., \& Gomes, N.P. (2010). E-health in Brazil: Less care for the poor? Biomedical Knowledge Management: Infrastructures and processes for e-health. IGI Global.

Rodrigues, J. (1988). Urban hospital cesarean section delivery rates in Paraíba State, Brazil (1977-1981). Am J Public Health, 78(6), 704-705. https://doi.org/10.2105/AJPH.78.6.704

Ross, D. (2013). Social Sustainability. Encyclopedia of Corporate Social Responsibility. Springer Berlin Heidelberg, pp. 2245-2249. https://doi.org/10.1007/978-3-642-28036-8_58

Shakila, U., Björklund, A., Ekener-Petersen, E. (2013). Social Life Cycle Inventory and Impact Assessment of Informal recycling of Electronic ICT Waste in Pakistan, ICT4S 2013, pp. 52-58, International Conference on Information and Communication Technologies for Sustainability

Silva, A. B., \& Moraes, I. H. S. (2012). O caso da rede universitária. Physis Revista de Saúde Coletiva, 2(3), 1211-1235. https://doi.org/10.1590/S0103-73312012000300019

Walsham, G., \& Sahay, S. (2006). Research on information systems in developing countries: current landscape and future prospects. Information Technology for Development, London, 12(1), 1-18. https://doi.org/10.1002/itdj.20020

Watson, R., Boudreau, M., \& Chen, A. (2010). Information systems and environmentally sustainable development: energy informatics and new directions for the IS community. MISQ, 34(1), 23-38. https://doi.org/10.2307/20721413

WCED (World Commission on Environment and Development). (1987). Our Common Future. London: Oxford University Press.

Weber, C. L., Koomey, J. G., \& Matthews, H. S. (2010). The energy and climate implications of different music delivery methods. Journal of Industrial Ecology, 14(5). https://doi.org/10.1111/j.1530-9290.2010.00269.x 
WHO Global Observatory for eHealth. (2010). Telemedicine: opportunities and developments in Member States: report on the second global survey on eHealth. Geneva: World Health Organization. Retrieved from http://www.who.int/iris/handle/10665/44497

WRF (World Resources Forum). (2008). Draft Declaration of the World Resources Forum, Empa, SATW, Factor 10 Institute, St. Gallen. Retrieved from http://www.worldresourcesforum.org/declaration

\section{Copyrights}

Copyright for this article is retained by the author, with first publication rights granted to the journal.

This is an open-access article distributed under the terms and conditions of the Creative Commons Attribution license (http://creativecommons.org/licenses/by/4.0/). 